\title{
A Comparative Study of Students' and Teachers' Perceptions About English Textbooks at Intermediate Level and Their Role in Promoting Students' Proficiency in English
}

\author{
Kifayatullah Khan ${ }^{1}$, Wasal Khan ${ }^{2}$, Yousaf Hayat ${ }^{3}$, Syed Munir Ahmad ${ }^{4} \&$ Khisro Kaleem Raza ${ }^{5}$ \\ ${ }^{1}$ Agricultural University Public School and College, The University of Agriculture, Peshawar, Pakistan \\ ${ }^{2}$ Sarhad University of Science \& Information Technology, Peshawar, Pakistan \\ ${ }^{3}$ Department of Maths, Stats and Computer Sciences, The University of Agriculture, Peshawar, Pakistan \\ ${ }^{4}$ Institute of Education and Research, University of Peshawar, Pakistan \\ ${ }^{5}$ Sarhad University of Science \& Information Technology, Peshawar, Pakistan \\ Correspondence: Kifayatullah Khan, Principal, Agricultural University Public School and College, The \\ University of Agriculture, Peshawar, Pakistan. E-mail: kifayat@aup.edu.pk
}

Received: October 20, 2019 Accepted: December 8, 2019 Online Published: January 18, 2020

doi:10.5539/ijel.v10n2p40 URL: https://doi.org/10.5539/ijel.v10n2p40

\begin{abstract}
The main aim of the study was to compare students' and teachers' perceptions about English Textbooks of Khyber Pakhtunkhwa Textbook Board for Intermediate Level, their contents and effects on students' proficiency in English. The main focus of this study was to find out that as to what extents these textbooks cater to the language needs of the 11th and 12th grade students. Objectives of the study were (a) to analyze the perceptions of students and teachers about the English Textbooks of Khyber Pakhtunkhwa Textbook Board for class XI and XII. (b) to find out as to what extents these books are helpful in promoting students' proficiency in English language. (c) to propose recommendations for further improvement in the existing English textbooks and teaching methods of teachers. The population of the study consisted of all the Intermediate level students and English Subject Specialists/Professors in Khyber Pakhtunkhwa. Data were collected from 1975 students and 108 English language teachers through pre-tested questionnaires one each for students and teachers in seven districts of Khyber Pakhtunkhwa. To analyze the difference between students' and teachers' perceptions about the English textbooks and their effects on students' proficiency in English, independent samples t-test was applied. The results of the study showed significant differences in students' and teachers' perceptions about the textbooks and their role in affecting students' proficiency in English.
\end{abstract}

Keywords: proficiency in English, English textbook for 11th and 12th grade students, students' and English language teachers' perceptions

\section{Introduction}

In today's globalized world, English language enjoys a prominent status and is considered as the 'lingua franca' in many countries of the world. No one can ignore the importance of English teaching and learning because its knowledge can contribute a lot to one's personal and social status in the world (Varela, Polo, Garcia, \& Mertinez, 2010). Mansoor (2003, p. 21) considers learning of English language as a "socio-political" demand. In Pakistan, English is taught as a compulsory subject from primary to tertiary level and failure in English means failure in all subjects. According to Rahman (2004), English is the emblem of power and the younger generation has accepted its importance with open hearts because its knowledge opens up doors to white collar jobs. Daller and Phelan, cited in Ozowuba, (2018) regard proficiency in English as an essential factor for success in all academic subjects. Ashraf, cited in Aftab (2011) argues that the mushroom like growth of English medium schools both in the urban and rural areas of the country affirms the fact that demand for acquiring this language has significantly increased. Zohrabi, Sabouri and Behroozian (2012) state that most of the people in the world, especially students, work hard to acquire English language to develop their communication, knowledge and other skills to get entry into the global workforce. Kumar, Ahsan and Negi (2017) affirm that proficiency in English is mandatory for carrying out successful and persuasive communication. Nunan (2003, p. 605) considers proficiency in English as 
a basic requirement for success both in educational and professional career. He further states that 'One of the most common requirements in job advertisements is proficiency in English (another is computer skills)'.

Awan and Shafi (2016) maintain that despite the fact the demand for learning English has enormously increased, but students' proficiency in English presents a very dismal picture at all levels. Nath (2016) posits that it is very regrettable that students studying English language for 8 to 10 years fail to write an error free simple paragraph in English in their own words and can't communicate orally a simple message of at least five sentences fluently and confidently. Waseem, Naveed and Aziz (2015) point out that despite the fact people spend thousands of rupees to learn English language; the proficiency level of a vast majority of Pakistani learners is not up to the mark. They fail to find an entry into world class local or foreign Universities for undergraduate studies. These authors further claim that lack of proficiency in English badly affects students' achievement in other academic subjects taught through English. They mostly lack competency in all the four language skills i.e., listening, speaking, reading and writing, vocabulary, grammar, etc. (Dar \& Khan, 2015).

Textbooks play a pivotal role in the teaching and learning process because both teachers and students can easily access them and utilize them according to their needs (Mahmood, 2011). Textbooks, according to Tomlinson (2010) are a useful means of preparing students for examinations. They help teachers in reducing their preparation time for their class; help administrators to allocate lessons to teachers; standardize teaching; and, provide teaching that would be useful to any learner anywhere at a specified language level. Books are the major source of providing comprehensible input to the learners and maximum comprehensible input can ensure optimum output. Therefore, great care is necessary while writing/selecting textbooks for a specific level in a situation where textbooks are considered the core syllabus (Krashen \& Terrel, cited in Habib \& Umar, 2017). Ahour and Ahmadi (2012) view textbooks as the major source of conveying knowledge and required information to the learners in a simple and organized way. Geraldine 1 and Eruchalu $(2012$, p. 1) argue that textbooks are an essential part of teaching and learning in educational institutions and help teachers in creating effective lesson plans. They further state that separating textbooks from teaching-learning is just like 'divorcing the dancer from the dance'.

All the public, private and elite Government schools/colleges coming under the auspices of Board of Intermediate and Secondary Education, Khyber Pakhtunkhwa- Pakistan, teach the textbooks designed and prepared by the Text Book Board, Peshawar. The Text Book Board has brought a lot of changes in the design and contents of all the textbooks, including the English textbook, taught at the intermediate level. It is, therefore, necessary to analyze the textbooks in the light of students' and teachers' views to ascertain whether the English textbooks are according to the language needs of the students or not and to what extents these textbooks are helpful in promoting students' proficiency in English language.

\subsection{Objectives of the Study}

The following were the objectives of the study:

1) To compare the perceptions of students and teachers about the Intermediate English textbooks for class XI and XII in Khyber Pakhtunkhwa, Pakistan.

2) To find out as to what extents these books are helpful in promoting students' proficiency in English language.

3) To propose recommendations for further improvement in the existing English textbooks and teaching methods of teachers.

\subsection{Hypothesis of the Study}

The study tested the following null hypothesis developed for the study:

$\mathrm{H}_{0}$ : There is no significant difference between students' and teachers' perceptions about the Intermediate English textbooks in Khyber Pakhtunkhwa and their role in promoting students' proficiency in English.

\subsection{Significance of the Study}

This study will prove to be of immense importance both for the higher secondary students and English language teachers as it brings to light students' and teachers' perceptions about Intermediate English textbooks in a comparative manner. In the light of students' perceptions, the teachers can reflect on the mismatch between their pedagogy and students' learning needs. This will help English language teachers to improve their teaching methodology and language teaching skills to promote students' proficiency in English. The results of the study can be of equal benefit to both the English Textbook writers and designers. They can prepare such textbooks that are according to the language needs of the students. 


\section{Literature Review}

Textbooks are like guiding map that directs and instructs teachers in the delivery of their lessons and ideas (Tomlinson, 2008); facilitate curriculum change (McGrath, 2002); and are extremely valuable for teachers who are new, inexperienced and have low confidence in imparting ELT lessons in a communicative way (Mares, 2003; Tomlinson, 2008). Cortazzi and Jin, cited in Asghar (2010, p. 405) claim that a "textbook is seen as an authority and can also be viewed as an ideology in the sense that it reflects a worldview or cultural system, a social construction that may be imposed on teachers and students and that indirectly constructs their view of a culture". Sheldon in Aghazadeh (2015, p. 1115) considers textbooks as 'the invisible heart of any ELT program'. They provide the objectives of language learning; they function as a lesson plan and working agenda for teachers and learners. Both the learners and teachers can equally benefit from them. Hutchinson and Torres in Lawrence and Vimala (2012) consider the role of textbooks inseparable from the ELT classroom and say that they have an important and positive part to play in second language teaching. Grant $(1987$, p. 8) claims that 'Perfect book does not exist', yet efforts are to be made to include the best possible textbook in the course that is suitable for and appropriate to a specific group of learners. According to Bano (2005), textbook is the only and genuine source of knowledge available to the students and teachers. A properly planned textbook keeps both teachers and students on the right track and guards them against unnecessary repetitions (Deuri, 2012).

There are scholars who do not favor too much teacher's reliance on textbooks in the language classroom because they make teachers uncreative in teaching (Tomlinson, 2008) and uncritical of the contents and values presented in the textbook (MacGrath, 2002). Brumfit, cited in Aftab, Sheikh and William (2014, p. 145), regard textbooks as "masses of rubbish skillfully marketed". Teachers follow the course contents slavishly and never spend a single moment in preparing their lesson (Tomlinson, 2008). Textbooks should work as supporting materials for the teachers but should not dominate the entire classroom activities as MacGrath $(2002$, p. 4) asserts, "What is important is that teachers should see the course book not as the course but as an aid to fulfilling the aims and objectives which they have themselves formulated".

Angulo (2014) posits that most of the English teachers use English textbooks as a primary source in the classroom; however, some of these textbooks fail to address students' needs and interests in the desired way. The given activities in the books are not according to the language learning needs of the students. So, it is obligatory for a teacher to have the required expertise in selecting such pedagogical materials that really help students in promoting their proficiency in the target language. Teachers should not rely too much on textbooks, but use them as supplementary means to teach the lesson.

Tomlinson (2010) is of the view that language learning should be an interesting and interactive activity. It should not be restricted to the structure imposed by the textbook because a small number of textbooks writers have really applied language learning principles while composing the materials. Issues like target learners' and teachers' background, their needs and language learning principles are to be given due consideration before developing a textbook (Tomlinson \& Masuhara, 2010). Mares, quoted in Aftab (2011, p. 52), contends that the speaking activities used in most of the textbooks are "contextualized functional drills which are often highly controlled". Many of the textbooks fail to promote students' English language efficiency because they are produced according to the public demand, rather than students' needs and interests. Moreover, teachers show preference for books that involve minimal preparation for their class (Tomlinson, 2008, 2010).

Textbooks from pre-primary to higher secondary level are developed by the Textbook Boards and private publishers by involving subject and pedagogical experts from all over the country which are later on evaluated by the Curriculum Wing and Ministry of Education with the assistance of Textbook Review Committee. After the recommendation of the committee, the ministry approves the textbook for teaching in the schools/colleges (Mahmood, Iqbal, \& Saeed, 2009).

Aftab (2011); Shah, Majeed, Waheed and Anjum (2013) argue that while designing textbooks for the higher secondary level in Pakistan, the learning needs and requirements of the learners are never taken into consideration. These books encourage rote learning and enable the students just to pass the examination with good marks. The contents of textbooks are outdated, have no immediate connection with real life situations and are deficient in improving the four basic language skills like listening, speaking, reading and writing. These textbooks have no attraction for the students and fail to develop their creative and intellectual curiosity.

Authors like Tomlinson, Richards and Crawford cited in Aftab (2011, pp. 53-54) propose the selection of such textbooks that ensure learners' participation in a real and valuable learning environment where they never feel overburdened with knowledge, but rather enjoy the learning process. These books should not only promote their creative and analytical skills but also be learner-centered and discovery-based. Moreover, the course books 
"...should present authentic language and the activities should be conceptualized, realistic, meaningful and purposeful". Above all, these books should contribute towards effective language outputs; make the learners realize that the materials are useful and relevant; and also make them feel that they have acquired something useful from them.

Tomlinson in Aftab (2011, p. 60) is of the view that $85 \%$ language textbooks in schools are selected by administrators whereas the rest $15 \%$ by teachers. This mechanism of course books selection is in vogue in Pakistani private schools where imported textbooks are prescribed on the basis of their surface appearance and not on the basis of critical evaluation of the course contents.

Asghar (2010) evaluated English textbook taught at higher secondary level in Punjab, Pakistan. Data were collected through a questionnaire and interviews from randomly selected 150 male and female students living in the city of Lahore, Pakistan. The analysis of the data revealed major faults in the teaching methodology and the philosophy of education as both of these fails to make the learners critical and independent learners. The book also fails to promote students' proficiency in the target language i.e., English. Moreover, the participants' responses revealed English teachers' incompetency to teach the effectively. Another study was carried out by Aftab, Sheikh and William (2014) to evaluate Intermediate English Textbook "Prose and Heroes" taught as a compulsory English course book at XI and XII level in Lahore, Pakistan. Mixed methods approach was used to know students' and teachers' perspectives about the book in question. Both the learners and teachers expressed dissatisfaction with the selected textbook because neither it helped students in improving their productive skills nor it motivated them for extensive reading. They further stated that the book mainly represented American/European culture, rather than Pakistani culture(s).

Shoukat and Ghani (2015) conducted research to know the opinion of English language teachers, teaching English at higher secondary level in the public schools of Punjab, Pakistan and came to the conclusion that majority of the teachers (both male and female) were not satisfied with the textbooks taught at the Higher Secondary level. Naseem, Shah and Tabassum (2015) echo similar view while evaluating the English textbook prescribed by the Punjab Textbook Board for 9th class and reported flaws both in the outward appearance and contents of the book in question. To them, the book is designed not according to the learning needs of the students and fails to promote the four basic language skills of the students. Both audio-visual aids are missing and provides no room for enhancing learners' cognitive and creative skills.

Lodhi et al. (2019) conducted a research study to evaluate English textbook "Good-bye Mr. Chips" taught at Intermediate level in Punjab, Pakistan. The participants were 200 Intermediate students (male and female) from both public and private sector in district Multan. Data were collected through a questionnaire. They concluded from the data analysis that the book was not up to the test of the students and teachers as it failed to promote linguistic skills of students. There was no balance among the four language skills. Moreover, while teaching the book English teachers did not organize activities in the classroom to make it attractive for the students.

Zohrabi, Sabouri and Behroozian (2012) carried out a study to analyze the merits and demerits of Iranian first year high school English textbook. Data were collected through a closed-ended questionnaire from 126 male and female language students. The findings of the study highlighted both strengths and weaknesses of the book. Outward appearance, font size, binding and fastening were found to be very attractive; however, the weaknesses included: lack of AV aids, CDs, workbook and activities for promoting students' listening and pronunciation skills.

Another study was conducted by Akef (2015) to evaluate the 2nd Intermediate stage English textbook "Iraq Opportunities". Random sampling technique was used for the selection of secondary schools and English teachers. A checklist was distributed among 26 male and 36 female teachers to collect the data. Statistical analysis of the data revealed serious flaws in the outward appearance of the book, its objectives, teaching aids and contents domain. The book also lacked background information, pedagogical guidance for the teachers and did not promote free writing skills of the students.

Aftab (2011, p. 346) concludes her discussion with the remarks that majority of the English textbooks prescribed in Pakistan are ineffective because they do not cater to the communicative competence of the target learners. Most of the shortcomings found by her in Pakistani English textbooks are in line with those pointed out by linguists (Tomlinson, 2003, 2008; Mares, 2003) in language textbooks.

It is due to the inadequacy and low quality of textbooks that the situation of learning and teaching English in Pakistan has been dismal and ineffective (Khalid, 2011). Warsi (2004) opines that the English course books are being prescribed without considering the learners' knowledge level of the target language. However, authors like Abbas (1998), Khan and Khan (2016), Mansoor (2003) and Warsi (2004) hold flawed pedagogy and inadequate 
teaching materials equally responsible for students' lack of proficiency and poor results in the subject of English. Maldonado Garcia (2018) also found that the lack of proper training for English language teachers and their ineffective teaching methodologies were the main reasons behind Pakistani students' low proficiency in English. According to William, cited in Tabassum (2018), textbook is an essential tool in any language classroom, but it is the teacher who should know the art of making it interesting and useful for the students. A study by Kabir (2015) revealed that due to the lack of proper training, majority of English language teachers in Bangladesh face problems in teaching the newly designed EFL textbook effectively. It further indicated that even experienced and trained up English language teachers use grammar-translation method in teaching the said English textbook which instead of promoting students' analytical and creative skills, encourages them to memorize the answers of the questions that are likely to come in the exam paper. These teachers often fail to engage students in creative and communicative activities in the classroom to facilitate communicative language skills. Similar were the findings of Asghar (2010) while analyzing an English textbook taught at higher secondary level in Punjab, Pakistan. He recommends such an effective pedagogical approach to the concerned English textbook that may enable both the teacher and the taught to meet the objectives as laid out in the national curriculum.

Warsi (2004) asserts that the language proficiency of the learners can be improved if appropriate English language textbooks are provided to the target learners. Luckily, there exists a glut of books related to teaching English as second language in Pakistan. This excess of English language textbooks in the market, has made the job of the policy makers and curriculum developers quite easier to choose the books that are according to the mental and proficiency level of the learners so as to achieve the required curricular objectives (ibid). Shah (2004) in the light of teachers' suggestions regarding English course books advocates that change in the textbooks is the need of the day for improving students' language learning. The textbooks should be revised having more space for the development of the four basic skills of English language and communicative competence of the target learners. Moreover, such books need to be developed that focus not only on enhancing theoretical, but also practical knowledge of the students and ensure their participation in the learning activities.

From the above discussion, it is crystal clear that textbooks are the major source of knowledge for both teachers and learners and their importance cannot be denied in the second language classroom in Pakistan. Being an integral part of the English language classroom, care must be taken while designing English language textbooks at the higher secondary level. They should be so designed that may prove an object of interest for the teachers and the taught and develop the creative and communicative skills of the learners.

Moreover, the materials in the textbooks should also be carefully planned so that they may relate to the teaching objectives and utilize activities that are motivating, involving and present English in a systematic and comprehensive way.

\section{Methodology}

The study was delimited to compare the perceptions of Govt. higher secondary schools/colleges students and teachers about the English textbooks, its contents and method of teaching published by the Khyber Pakhtunkhwa Textbook Board, Peshawar for the 11th and 12th grade students.

\subsection{Population and Sample}

The population of the study comprised all the11th and 12th grade students of the Government Higher Secondary Schools and Colleges (Boys only) enrolled in the session 2016-2017 in the Khyber Pakhtunkhwa province. The population also included Subject Specialists (SS) and lecturers involved in teaching English to the afore-mentioned classes throughout the province. A multi-stage sampling procedure was followed (Siddiqui, 2010; Kalsoom, 2013). In stage 1, out of all seven administrative divisions, one district from each division was selected purposively. In stage 2 , from each selected district, a minimum of 10 or above schools/colleges were randomly selected. The total number of the sampled schools and colleges was 89 ( 29 urban and 60 rural). Then in stage 3, at least 24 students from each school/college were randomly selected. Thus, the total number of sampled students was 2136 . In stage 4, 125 subject specialists and lecturers/professors were also randomly selected from these schools/colleges with a minimum of one SS from each GHSS and two lecturers from each college. While selecting schools and colleges, it was kept in mind that the data represented the whole population and all factors.

\subsection{Tools of data Collection}

Two closed questionnaires (one each for students and English teachers) were developed to collect the data from the sampled students and teachers of the sampled institutions. The main purpose behind using close-ended questionnaires was to make them easier and less time consuming for the respondents to fill, and to obtain 
information according to the objectives of the given study.

\subsection{Data Collection}

The investigator personally visited all the sampled schools and colleges and administered the questionnaires to the sampled teachers and students after obtaining permission from the concerned principals. With the permission of the principals, the researcher randomly selected 24 students, twelve each, from 11th and 12th classes and briefed them thoroughly about filling the questionnaire. The researcher supervised the whole process of the filling up the questionnaires. The total number of the students' filled questionnaires was 1975 and that of teachers was 108 .

Cronbach alpha coefficient was used for checking the reliability of the collected data from students and teachers about different attributes of promoting students' regarding English language proficiency at the higher secondary level. The data was considered reliable having Cronbach Alpha coefficient greater than or equal to 0.70 .

\subsection{Data Analysis}

To investigate significant differences, if any, between the average perception of students and teachers regarding students' English language proficiency, independent samples t-test was applied.

The Mean was analyzed as per the following scale:

The Mean $=1.00-1.50=$ No

The Mean $=1.51-2.50=$ Uncertain

The Mean $=2.51-3.00=$ Yes

Table 1. Comparison of average perceptions of students and teachers regarding English textbooks at intermediate level and its contents

\begin{tabular}{|c|c|c|c|c|c|}
\hline Attributes & Group & Mean & SD & t-ratio & $\mathrm{p}$-value \\
\hline \multirow{2}{*}{ Q1. The English textbook fulfills the language needs of the students. } & Students & 1.59 & 0.825 & \multirow[t]{2}{*}{-14.026} & \multirow[t]{2}{*}{0.000} \\
\hline & Teachers & 2.60 & 0.723 & & \\
\hline \multirow{2}{*}{$\begin{array}{l}\text { Q2. The organization of materials is in a logical sequence i.e., from } \\
\text { known to unknown. }\end{array}$} & Students & 2.47 & 0.854 & \multirow[t]{2}{*}{-8.689} & \multirow[t]{2}{*}{0.000} \\
\hline & Teachers & 2.86 & 0.420 & & \\
\hline \multirow{2}{*}{$\begin{array}{l}\text { Q3. English textbooks give equal importance to all the four language } \\
\text { skills. }\end{array}$} & Students & 2.29 & 0.888 & \multirow[t]{2}{*}{-10.988} & \multirow[t]{2}{*}{0.000} \\
\hline & Teachers & 2.86 & 0.502 & & \\
\hline \multirow{2}{*}{$\begin{array}{l}\text { Q4. Textbooks have activities for improving all the four language } \\
\text { skills. }\end{array}$} & Students & 2.18 & 0.942 & \multirow[t]{2}{*}{1.880} & \multirow[t]{2}{*}{0.060} \\
\hline & Teachers & 2.00 & 0.957 & & \\
\hline \multirow[t]{2}{*}{ Q5. Course contents match students' capabilities. } & Students & 2.18 & 0.927 & \multirow[t]{2}{*}{3.595} & \multirow[t]{2}{*}{0.000} \\
\hline & Teachers & 1.85 & 0.905 & & \\
\hline \multirow{2}{*}{ Q6. The course contents are closely related to students' local culture. } & Students & 1.89 & 0.967 & \multirow[t]{2}{*}{-21.844} & \multirow[t]{2}{*}{0.000} \\
\hline & Teachers & 2.89 & 0.418 & & \\
\hline \multirow{2}{*}{ Q7. The English textbook is very interesting. } & Students & 2.59 & 0.794 & \multirow[t]{2}{*}{2.474} & \multirow[t]{2}{*}{0.015} \\
\hline & Teachers & 2.37 & 0.892 & & \\
\hline \multirow{2}{*}{$\begin{array}{l}\text { Q8. The subject and contents of the textbooks are challenging and } \\
\text { motivating. }\end{array}$} & Students & 2.49 & 0.846 & \multirow[t]{2}{*}{4.525} & \multirow[t]{2}{*}{0.000} \\
\hline & Teachers & 2.07 & 0.944 & & \\
\hline \multirow{2}{*}{$\begin{array}{l}\text { Q9. The textbook motivates students to study English language in } \\
\text { future. }\end{array}$} & Students & 2.63 & 0.736 & \multirow[t]{2}{*}{8.442} & \multirow[t]{2}{*}{0.000} \\
\hline & Teachers & 1.86 & 0.932 & & \\
\hline \multirow{2}{*}{$\begin{array}{l}\text { Q10. The English Textbook facilitates the learning of other course } \\
\text { books. }\end{array}$} & Students & 2.21 & 0.942 & \multirow[t]{2}{*}{2.592} & \multirow[t]{2}{*}{0.010} \\
\hline & Teachers & 1.97 & 0.961 & & \\
\hline
\end{tabular}

Significant difference was indicated (p-value less than 0.05) when analyzing students' and teachers' views regarding English textbooks fulfilling the language needs of the students. The students showed uncertainty with Mean 1.59 and $\mathrm{SD}=0.823$; whereas teachers favored the statement with Mean 2.60 and $\mathrm{SD}=0.723$. Similarly, significant difference was pointed out while comparing students' and teachers' perceptions about the organization of materials in the textbooks. Teachers strongly favored the statement that the materials in the textbooks were in a logical sequence i.e. from known to unknown. Their Mean 2.86 with $\mathrm{SD}=0.420$ clearly authenticated their favor for the statement. However, students showed uncertainty about the statement. Their Mean 2.47 with $\mathrm{SD}=0.854$ confirmed the same.

Significant difference was noted (p-value less than 0.05 ) while comparing students' and teachers' perceptions about the English textbooks giving equal importance to all the four language skills. Students' Mean Score 2.29 
and $\mathrm{SD}=0.888$ showed their uncertainty about the statement while teachers' Mean 2.86 and $\mathrm{SD}=0.502$ strongly favored the statement. But teachers' Mean Score 2.00 and SD $=0.957$ showed uncertainty when responding to the statement that the textbook has activities for improving students' all language skills. Close similarity was observed in students' and teachers' perceptions $\mathrm{p}>0.05$.

Significant difference was pointed out $(\mathrm{p}<0.05)$ while comparing students' and teachers' perceptions with regard to statement 5, 6, 7 and 8. The Means of both students and teachers 2.18 and 1.85 and Standard Deviations 0.927 and 0.905 clearly indicated their uncertainty about the course contents matching students' capabilities. It showed that neither students nor teachers had critically analyzed the course contents to ascertain whether they match students' capabilities or not. Further, students displayed considerable uncertainty with Mean 1.89 and $\mathrm{SD}=0.967$ to the statement that course contents are closely related to students' local culture. However, teachers strongly favored the statement with Mean 2.89 and $\mathrm{SD}=0.418$.

The students' Mean 2.59 and SD $=0.794$ revealed that the textbook was very interesting whereas teachers were uncertain about the statement. Teachers' Mean 2.37 and $\mathrm{SD}=0.892$ confirmed the same. Similarly, to majority of the students, the subjects and contents of the textbooks were challenging and motivating and the same was evident from their Mean 2.49 and $\mathrm{SD}=0.846$ but again teachers showed uncertainty about the statement. Their Mean 2.07 and SD $=0.944$ endorsed the same. Further, substantial uncertainty was expressed by both students and teachers while responding to the statement that the English textbooks facilitate the learning of other course books. Their respective Means 2.21 and 1.97 with $\mathrm{SD}=0.942$ and 0.961 validated their statements. It clearly shows teachers' disinterest in their students and the textbooks taught at the intermediate level. It also demonstrates their lack of deep insight into the textbooks and interaction with the students.

Table 2. Students' and teachers' perceptions about the length of the English textbook, role in language development, vocabulary and the way it is taught

\begin{tabular}{|c|c|c|c|c|c|}
\hline Attributes & Group & Mean & SD & t-ratio & p-value \\
\hline \multirow{2}{*}{$\begin{array}{l}\text { Q1. English syllabus is very large and does not help in improving } \\
\text { students' language skills. }\end{array}$} & Students & 1.91 & 0.943 & -4.381 & 0.000 \\
\hline & Teachers & 2.31 & 0.901 & & \\
\hline \multirow{2}{*}{$\begin{array}{l}\text { Q2. The language used in the textbooks is easy and } \\
\text { comprehensible. }\end{array}$} & Students & 1.86 & 0.933 & -20.338 & 0.000 \\
\hline & Teachers & 2.83 & 0.463 & & \\
\hline \multirow{2}{*}{$\begin{array}{l}\text { Q3. Students can use the textbook vocabulary in their day to day } \\
\text { life. }\end{array}$} & Students & 2.87 & 0.472 & 4.775 & 0.000 \\
\hline & Teachers & 2.48 & 0.848 & & \\
\hline \multirow[t]{2}{*}{ Q4. Teachers teach the textbook through GTM only. } & Students & 1.69 & 0.862 & -19.786 & 0.000 \\
\hline & Teachers & 2.78 & 0.535 & & \\
\hline \multirow{2}{*}{$\begin{array}{l}\text { Q5. Teachers arrange different activities in the classroom while } \\
\text { teaching the textbook. }\end{array}$} & Students & 1.49 & 0.820 & -22.561 & 0.000 \\
\hline & Teachers & 2.79 & 0.565 & & \\
\hline \multirow[t]{2}{*}{ Q6. The exercises promote critical thinking of the students. } & Students & 2.47 & 0.854 & -8.689 & 0.000 \\
\hline & Teachers & 2.86 & 0.420 & & \\
\hline \multirow{2}{*}{$\begin{array}{l}\text { Q7. English teachers use materials other than the textbooks in the } \\
\text { classroom. }\end{array}$} & Students & 1.33 & 0.699 & -30.644 & 0.000 \\
\hline & Teachers & 2.83 & 0.483 & & \\
\hline
\end{tabular}

Significant difference was pointed out $(\mathrm{p}<0.05)$ while comparing students' and teachers' perceptions with regard to statement 11,12 and 13 . Uncertainty was seen among students and teachers regarding the length of the syllabus and its role in improving students' language skills with Mean 1.91 and 2.31 and Standard Deviation 0.943 and 0.901 . This clearly demonstrated that neither students nor teachers had in-depth study of the concerned English textbooks. A majority of the students with Mean 2.63 and $\mathrm{SD}=0.736$ indicated that the contents of the textbooks motivated them to study English language in future. However, they showed uncertainty while responding to the statement that the language used in the textbooks is easy and comprehensible with Mean 1.86 and $\mathrm{SD}=0.933$. Yet, they strongly favored the statement that they can use the textbooks' vocabulary in their day to day life with Mean 2.87 and SD $=0.472$. All this clearly shows their non-serious attitude and approach towards their study and the textbooks. On the other hand, teachers showed uncertainty about textbooks role in motivating students to study English language in future with Mean 1.86 and SD $=0.932$; however, they strongly favored the statement that the language used in the textbooks was easy and comprehensible with Mean 2.86 and $\mathrm{SD}=0.463$. Further, little uncertainty was observed in teachers' views while responding to the statement that students can use the textbooks vocabulary in their day to day life with Mean Score 2.48 and SD $=0.848$.

Significant difference was seen $(\mathrm{p}<0.05)$ while comparing students' and teachers' perceptions with regard to statement 15,16,17 and 18. Great contradiction was noted in teachers' own opinions while responding to 
statement 15 and 16. Teachers' Mean 2.78 with $\mathrm{SD}=0.535$ clearly indicated that they taught English through GTM only but, they also claimed that they engaged students in different activities in the classroom while teaching the textbooks. Their Mean 2.79 and SD $=0.565$ clearly affirmed their claim. On the other hand, students were not sure whether teachers taught through GTM or not. Their Mean 1.69 with SD $=0.862$ also validated their claim. Further, students denied teachers' claim that different activities were arranged while teaching the textbooks. Their Mean 1.49 with $\mathrm{SD}=0.820$ authenticated their claim to the statement. This clearly illustrates that teachers play a dominant role in the classroom and students are treated as silent spectators who know nothing and can do nothing.

Further, significant difference was perceived $(p<0.05)$ while analyzing students' and teachers' views with respect to the exercises promoting critical thinking of the students. A majority of the teachers went in favor of the statement which was verified by their Mean 2.86 and $\mathrm{SD}=0.420$. However, students displayed a little uncertainty with Mean 2.47 and $\mathrm{SD}=0.854$ to the statement. Furthermore, students clearly denied that English teachers used materials other than the English textbooks in the classroom. Their mean 1.33 with $\mathrm{SD}=0.699$ corroborated their statement. Nonetheless, a huge majority of the teachers strongly supported the statement with Mean 2.83 and $\mathrm{SD}=0.483$. This clearly shows that teachers never engage students in activities to develop their critical thinking and thus promote their language skills. Moreover, English teachers never supplement the textbooks with extra authentic materials to enhance students' communicative competency in the target language (Crookes, cited in Trisha, 2016).

\section{Conclusion}

Contradictory views of students and teachers came to the front while analyzing their perceptions about the English textbooks taught at the higher secondary levels. The results clearly indicated that neither students nor teachers had an in-depth study and knowledge of the textbooks. A dominant majority of the responding teachers strongly favored the statement that the textbooks gave equal importance to all the language skills but showed uncertainty when responding to the statement that textbooks had activities for improving students' language skills. Similarly, teachers admitted that they taught English through GTM but strongly favored the statement that they arrange different activities in the classroom while teaching the textbooks. Further, they claimed that the language used in the textbooks is easy and comprehensible but displayed little uncertainty whether students can use the textbooks vocabulary in their day to day life or not. All this demonstrated a clear contradiction in teachers' views and alludes to their lack of subject matter knowledge. The results of the study strongly support the findings of Haider, Hameed and Ameen (2015); Shakir and Adeeb (2014) who concluded that majority of the English teachers have moderate level of competence in subject matter knowledge. Similarly, the findings of Shakir, Hussain and Zaffarc (2011) clearly indicated that a good majority of the teachers usually lack full understanding of their subject knowledge and rarely try to update their knowledge about the subject they teach; hence, they fail to establish relationship of the related subject with other course books. Richards $(2001$, p. 1) considers it 'an important part of a teacher's professional knowledge' to learn how to use and adapt textbooks. The results also support Warsi's (2004) views that majority of the English language teachers in public sector schools lack proper training and adequate knowledge of the academic curricula which adversely affect students' second language acquisition. This alludes to the fact that English is being taught as a compulsory subject in Pakistan from nursery to tertiary level, but due to flawed pedagogy the results are not encouraging (Abbas, cited in Khan, Zahid, \& Akhtar, 2017).

Like teachers, great contradiction came to the front while analyzing students' perceptions about the English textbooks. On one hand, students showed uncertainty while responding to the statement that English textbooks give equal importance to all the four language skills but strongly favored the statement that the textbooks motivate students to study English language in future. Further, they showed uncertainty to the statement that language used in the textbooks was easy and comprehensible but strongly favored the statement that they can use the textbooks vocabulary in their day to day life.

\section{Recommendations}

On the bases of the results and findings of the study, following recommendations are made to further improve the teaching and learning of the Intermediate English textbooks XI and XII.

1) The present English Textbooks XI and XII have been prepared by language experts according to the language needs of the students; therefore, they can prove of immense importance in improving students' language competency if taught properly.

2) Teachers should be properly trained to teach the textbooks by adapting the modern teaching methodologies. They should not rely only on one method of teaching i.e., GTM but use different methods to develop students' 
interest and their proficiency in English language.

3) Teachers should develop an in-depth understanding of the course contents of the English textbooks. Students should also be involved in creative activities to enable them to devise ways for developing their critical thinking and relating course contents to the outer world.

4) Teachers are advised to supplement English textbooks with other related materials to make their teaching interesting and result oriented. This is possible only when the teachers come to the class with a lesson plan and audio-visual aids.

5) Students are advised to come well prepared to the class and speak English both with teachers and their class fellows. They should ask questions from their teachers to make him/her come well prepared to the class.

\section{References}

Abbas, S. (1998) Sociopolitical Dimensions in Language: English in Context in Pakistan. Journal of Applied Language Studies, 23, 42.

Aftab, A. (2012). English language textbooks valuation in Pakistan. Birmingham, Doctoral dissertations, University of Birmingham, UK.

Aftab, A., Sheikh, A., \& William, I. (2014). An evaluation of an English as a second language (ESL) Pakistani college textbook: Meeting the needs of the Pakistani students. International Journal of English and Literature, 5(7), 144-148. https://doi.org/10.5897/IJEL2013.0520

Aghazadeh, Z. (2015). An evaluation of high school English textbooks in Iranian EFL context: Teachers' versus learners' perceptions. Journal of Language Teaching and Research, 6(5), 1115-1124. https://doi.org/10.17507/jltr.0605.26

Ahour, T., \& Ahmadi, E. (2012). Retrospective evaluation of textbook "Summit 2B" for its suitability for EFL undergraduate students. Journal of Educational and Social Research, 2(5), 195-202.

Akef, H. D. (2010). Evaluating the English textbook "Iraq Opportunities" Book 6 for the 2nd Intermediate Stage. Al-Ustath, 215, 105-132.

Angulo, J. E. V., \& Mianda, A. G. C. (2014). Evaluating a textbook's efficiency to enhance students' English proficiency in a Costa Rica's Rural School. Revista De Lenguas Modernas, 20, 395-425.

Asghar, J. (2010). Critical investigation into a textbook for actual and potential uses in Pakistani higher secondary education. UK: University of Warwick Publication Services \& WRAP.

Asghar, J. (2010a). Change for the better: An evaluative study of an English textbook. Journal of International Scientific Publications: Language, Individual \& Society, 7(1), 404-422.

Awan, A. G., \& Shafi, M. (2015). Analysis of teaching methods of English language at Government secondary school level in D. G. Khan City-Pakistan. Global Journal of Management and Social Sciences, 2(2), 29-46.

Bano, Y. (2005). Curriculum and textbooks: Issues and challenges in Pakistan. ANTRIEP Newsletter, 10(1), 3-8.

Dar, M. F., \& Khan, I. (2015). Writing anxiety among public and private sectors Pakistani undergraduate university students. Pakistan Journal of Gender Studies, 10, 157-172.

Deuri, C. (2012). An evaluative study of textbook in English at higher secondary level. International Journal of Science, Environment and Technology, 1(1), 24-28.

Dr. Shakir, M., Dr. Hussain, I., \& Zaffarac, J. M. (2011). Are the teachers on track? An evaluation of Secondary school teachers' subject knowledge competency. International Journal of Management Research and Emerging Sciences, 1(1), 74-85.

Geraldine, I., \& Eruchalu, N. (2012). The role of textbooks in effective teaching and learning of English as a second language. Nigerian Journal of Curriculum and Instruction, 20(1),1-6.

Grant, M. (1987). Making the most of your textbook. London: Longman.

Guerrettaz, A. M., \& Johnston, B. (2013). Materials in the classroom ecology. Modern Language Journal, 97 , 779-796. https://doi.org/10.1111/j.1540-4781.2013.12027.x

Habib, A., \& Umar, H. (2017). A qualitative inquiry into the alignment of English textbooks with the National Curriculum at secondary level. NUML Journal of Critical Inquiry, 15(II).

Kabir, M. H. (2015). Managing curricular innovation and teacher training: Bangladesh perspective. IIUC Studies, 12, 9-26. https://doi.org/10.3329/iiucs.v12i0.30578 
Haider, Z., Hameed, Q., \&Ameen, S. (2015). Applying standardized rubrics for assessing the instructional competence of Elementary School Teachers (EST) in Pakistan. Advances in Social Sciences Research Journal, 2(3), 39-50. https://doi.org/10.14738/assrj.24.832

Khalid, A. (2016). A Study of the attitudes and motivational orientations of Pakistani learners toward the learning of English as a second language. SAGE, 6(3), 1-19. https://doi.org/10.1177/2158244016665887

Khan, T. J., \& Khan, N. (2016). Obstacles in learning English as a second language among Intermediate Students of Districts Mianwali and Bhakkar, Pakistan. Open Journal of Social Sciences, 4, 154-162. https://doi.org/10.4236/jss.2016.42021

Khan, T. J., Zahid, M., \& Akhtar, S. (2017). Obstacles in teaching English as a second language (ESL) among pre-university students in district Mianwali (Pakistan)-A Pakistani case study. International Journal of Pure and Applied Researches, 1(1), 62-72.

Kumar, A., Ahsan, M., \& Negi, M. (2017). A comparative study of proficiency in English and study of government and non-government schools students. International Journal of Informative and Futuristic Research, 5(1), 8764-8770.

Lawrence, A. A. S., \& Vimala, A. (2012). School environment \& academic performance of Standard Six Students. Journal of Educational and Industrial Studies in the World, 2(3), 210-215.

Lodhi, M. A., Farman, H., Ullah, I., Gul, A., Tahira, F., \&Saleem, S. (2019). Evaluation of English textbook of Intermediate class from students' perspectives. English Language Teaching, 12(5), 79-87. https://doi.org/10.5539/elt.v12n3p26

Mahmood, I., \& Saeed. (2009). Textbook evaluation through quality indicators: The Case of Pakistan. Bulletin of Education and Research, 31(2), 1-27.

Mahmood, K. (2011). Conformity to quality characteristics of textbooks: The illusion of textbook evaluation in Pakistan. Journal of Research and Reflections in Education, 5(2), 170-190.

Maldonado, G. M. I. (2018). Improving university students writing skills in Pakistan. The European Educational Researcher, 1(1), 1-16.

Mansoor, S. (2003). Language Planning in Higher Education Issues of Access and Equity. The Lahore Journal of Economics, 8(2), 17-42. https://doi.org/10.35536/lje.2003.v8.i2.a2

Mares, C. (2003). Writing a course book. In B. Tomlinson (Ed.), developing materials for language Teaching (pp. 130-140). London: Continuum.

McGrath, I. (2002). Materials evaluation and design for language teaching. Edinburgh: Edinburgh University Press.

Naseem, S., Shah, S. K., \& Tabassum, S. (2015). Evaluation of English Textbook in Pakistan: A case study of Punjab Textbook for 9th Class. European Journal of English Language and Literature Studies, 3(3), 24-42.

Nath., M. (2016). Problems in teaching English in secondary schools in North Tripura District. M. Phil. thesis, Savitribai Phule Pune University, India.

Nunan, D. (2003). The impact of English as a global language on educational policies and practices in the AsiaPacific region. TESOL Quarterly, 37(4), 589-613. https://doi.org/10.2307/3588214

Ozowuba, G. U. (2018). Relationship between English proficiency and academic achievement of Nigerian secondary school students. Walden: PhD Dissertations, Walden University, Minnesota, United States.

Rahman, T. (2004). Denizens of Alien Worlds: A study of education, inequality and polarization in Pakistan. Oxford: Oxford University Press.

Shah, M. S. (2004). A critical study on ELT and its impact on development of communicative skill of learners at Intermediate level in Pakistan. Jamshoro: PH.D. Thesis, University of Sindh.

Shah, S. K., Hassan, S., \& Iqbal, W. (2013). Evaluation of text-book as curriculum: English for 6 and 7 grades in Pakistan. International Journal of English Language Education, 3(2), 71-89. https://doi.org/10.5296/ijele.v3i2.8042

Shah, S. K., Majeed, R., Waheed, S. U., \& Anjum, M. A. I. (2013). Humanizing English textbooks evaluation at the higher secondary level in Pakistan. Language in India, 13(8), 481-499.

Shakir, M., \& Adeeb, A. M. (2014). Performance appraisal: An evaluation of teachers' competencies based on 
National Professional Standards in Pakistan. International Review of Social Science, 2(12), 532-539.

Shoukat, B., \& Ghani, M. (2015). English language teachers' opinion on Intermediate English Textbooks taught in Punjab Pakistan. Dialogue, 10(3), 313.

Tabassum, A. (2018). Evaluation of the higher secondary textbook "English For Today" from CLT perspective. Dhaka, Master Thesis, BRAC University, Bangladesh.

Tomlinson, B. (Ed.). (2008). English learning materials: A Critical Review. London: Continuum.

Tomlinson, B. (2010). Principles of effective materials development. In N. Harwood (Ed.), English language teaching materials: Theory and practice (pp. 81-98). Cambridge: Cambridge University Press.

Tomlinson, B., \& Masuhara, H. (2010). Published Research on Materials Development in Language Learning. In B. Tomlinson \& H. Masuhara (Eds.), Research for Materials Development in Language Learning (pp. 118). London: Continuum.

Trisha, A. H. (2016). A study on the role of textbooks in second language acquisition. Master Thesis, BRAC University, Dhaka.

Varela, M. C., Polo, F. J. F., Garcia, L. G., \& Martinez, I. P. (2010). Current issues in English language teaching and learning: An international perspective. Cambridge Scholars Publishing, US.

Warsi, J. (2004) Conditions under which English is Taught in Pakistan: An Applied Linguistic Perspective. Retrieved October 18, 2018, from tyyp://www.saridjournal.org/2004/warsi.html

Waseem, F., Naveed, A., \& Aziz, S. (2015). Does schooling make a difference in English language proficiency? A comparison of Pakistani undergraduate students coming from English and Urdu Medium Schools. European Academic Research, 3(8), 8628-8652.

Yahaya, A., Yahaya, N., Lean, O. C., Bon, O. T., \& Ismail, S. (2011). Factors contributing to proficiency in English as a second language among Chinese students in Johor Bahru. Elixir Psychology, 41, 5837-5848.

Zohrabi, M., Sabouri, H., \& Behroozian, R. (2012). An evaluation of merits and demerits of Iranian First Year high school English textbook. English Language Teaching, 5(8), 14-21. https://doi.org/10.5539/elt.v5n8p14

\section{Copyrights}

Copyright for this article is retained by the author, with first publication rights granted to the journal.

This is an open-access article distributed under the terms and conditions of the Creative Commons Attribution license (http://creativecommons.org/licenses/by/4.0/). 